\title{
Analysis of Porous Structure in Autoclaved Materials Modified by Glass Sand
}

\author{
Anna Stepien \\ Faculty of Civil Engineering and Architecture, Kielce University of Technology, al.1000-lecia PP 7, \\ 25-314 Kielce, Poland; ana_stepien@wp.pl
}

Citation: Stepien, A. Analysis of Porous Structure in Autoclaved Materials Modified by Glass Sand. Crystals 2021, 11, 408. https:// doi.org/10.3390/cryst11040408

Academic Editors: Nima Farzadnia and Anton Meden

Received: 2 March 2021

Accepted: 8 April 2021

Published: 12 April 2021

Publisher's Note: MDPI stays neutral with regard to jurisdictional claims in published maps and institutional affiliations.

Copyright: (C) 2021 by the author. Licensee MDPI, Basel, Switzerland. This article is an open access article distributed under the terms and conditions of the Creative Commons Attribution (CC BY) license (https:// creativecommons.org/licenses/by/ $4.0 /)$.

\begin{abstract}
This paper describes the use of glass sand in the production of autoclaved bricks. Traditional autoclaved materials consist of $\mathrm{SiO}_{2}, \mathrm{CaO}$, and $\mathrm{H}_{2} \mathrm{O}$. The purpose of the tests is to analyze the possibility of using glass sand in autoclaved materials and to determine their properties and durability. Depending on the structure, building materials can have porosities ranging from $0 \%$ (glass, metals) to over $90 \%$ (thermal insulation materials such as aerated concrete). Porosity of materials is directly related to the strength of materials and their density, and further to the thermal and acoustic insulation properties of products used especially for external wall construction, i.e., bricks, concrete, and aerated concrete. This type of silicate brick is formed at a temperature of $203{ }^{\circ} \mathrm{C}$, therefore the dominant phase forming the microstructure is tobermorite, in contrast to the C-S-H phase, which dominates in concretes and which is characterized by a larger specific surface. The nature of pores, their number, appearance and arrangement in the material can be studied using computer techniques (SEM, XRD, computed tomography, porosimetry). Computed tomography (micro-CT analysis) showed that the number of voids in the material modified by glass sand is about $20 \%$ in relation to the weight of the product. The density of the product with glass sand was determined to be $2.2 \mathrm{~kg} / \mathrm{dm}^{3}$.
\end{abstract}

Keywords: silica; autoclaved; pores; sand; glass; lime; tobermorite; micro CT

\section{Introduction}

Building materials are divided into natural and artificial. Among artificial building materials we can distinguish concrete, autoclaved bricks, autoclaved aerated concrete, and porous ceramic bricks. Autoclaved materials can be divided into two categories: aerated autoclaved concrete "AAC" (or aerated cellular concrete "ACC") and autoclaved bricks.

Concrete materials and autoclaved concretes have been fairly well researched in terms of their porosity, although these studies are still being extended, while silicate bricks are the second group of building construction materials and the data on them is still being supplemented. There are standards on how to test autoclaved materials, including silicate bricks, but data on their porous structure are still insufficient.

This article is another supplement to the research on the porosity of autoclaved bricks and their microstructure, which is important in research on the durability of materials. In addition, new research techniques were used, such as micro-CT analysis, which shows the amount, volume and distribution of pores in the analyzed sample.

Among these materials almost all are porous. According to IUPAC (International Union of Pure and Applied Chemistry), porous materials are solids having cavities, pores, channels, or fissures whose width is less than the depth [1]. On the surface of porous building materials, processes constantly occur, the course of which is related to the phenomena occurring at the phase boundary [1]. The porous structure of materials is formed at the boundaries of individual substrates (sand, aggregate, binder) and phases which are created starting from the hydration process of the binder, through the maturation of the material and then as a result of environmental conditions.

Depending on the structure, building materials can have porosities ranging from $0 \%$ (glass, metals) to over $90 \%$ (thermal insulation materials such as aerated concrete). The 
fraction of pore volume in AAC products covers the range from 65 to $90 \%$. There is a set of different types of pores, e.g., large air pores are a macroscopic structural element, capillary pores, and nano pores, which are connected to the microstructure of the solid matrix and have specific functional effects [2,3].

Porosity of materials is directly related to the strength of materials and their density, and further to the thermal and acoustic insulation properties of products used especially for external wall construction. When discussing the porosity of materials, it is important to consider how they are formed and the substrates and grain size of the components that form the basis of the various construction products. The number of macro- and micropores in the material is important in terms of the thermal properties of the materials, but also due to the strength properties and durability of these materials (the possibility of water penetration and migration in porous voids) [4].

Unfortunately, low strength is often associated with the very favorable thermal properties of the material (which is related to the large number of pores), as shown by the research of Guglielmi et al. The research concerned of the porosity and the mechanical strength of an Autoclaved Clayey Cellular Concrete (ACCC) with the binder produced with $75 \%$ kaolinite clay and $25 \%$ portland cement. Their results showed that in samples with higher aluminum content, pores coalesced, which could explain the lower porosity of the samples. The porosity obtained in the experiment was as much as $80 \%$, which resulted in the strength lowered to the level of $0.62 \mathrm{MPa}$ [5].

The nature of pores, their number, appearance and arrangement in the material can be studied using computer techniques (SEM, XRD, computed tomography, porosimetry (MIP)). Depending on the pore structure a distinction is made between:

- $\quad$ Absolute porosity (total pore volume) —includes all pores, both closed and open; and - $\quad$ Relative porosity-includes only open pores [6].

The main aspect of research in the article is the presentation of tests on the porous structure of traditional autoclaved bricks and bricks modified with glass cullet (90\% glass sand). Thus, all modifications of building materials are currently subject to trends focused on sustainable and green building. AAC is a material that perfectly fits the idea of sustainable development in the construction industry, but despite the modifications, it is characterized by low compressive strength (which allows the construction of walls only up to a maximum of two storeys, or one storey and an attic [7-9]. In tests conducted by Mindess on the characteristics of Calcium silicate hydrates and autoclaved materials, it was shown that the strength of materials decreases with an increase in the proportion of larger pores [10]. Therefore, when thinking about modifications of autoclaved materials in accordance with sustainable construction, it seems advantageous to use glass cullet, which exhibits the features of durable amorphous materials. This test shows how to use recycled glass sand as a substrate for brick production, which can help to combat the so-called overproduction and dwindling resources of sand and natural aggregates.

One of the significant challenges faced by the process of popularization of green building is not only the cost of the introduced technologies, but often also the high complexity of the buildings built over the 20th century, and today undergoing demolition processes. Therefore, it is necessary to use and introduce such modifications and components that can promote the recycling of materials. Silicate bricks are a natural and durable material (sand, lime and water) and all modifications are to maintain this property, because in recent years, silicate aggregate (i.e., crushed silicate bricks from buildings that have undergone the demolition process) has begun to be used in construction.

Existing solutions include:

- Sensory technology for the recovery of concrete and ceramics from mixed construction waste;

- A selective stripping technique for materials combined with concrete or ceramics to remove unwanted materials from grey and red fractions or from mixed waste (combinations of concrete and ceramics); 
- Advanced gypsum sorting and recycling systems to obtain high-purity fractions and integrated with infrared spectroscopy and X-ray fluorescence sensors; and

- New grinding and refining processes for the recovery of high-purity wood fibers, glass and mineral wool. These will allow up to $20 \%$ of traditional gypsum board and at least $60 \%$ of polymer-wood composites to be replaced with eco-friendly materials.

Recovered raw materials can be used to produce innovative and green building materials, such as low-carbon cements with low $\mathrm{CO}_{2}$ emissions, green concrete containing at least $1300 \mathrm{~kg}$ of recovered aggregate per $\mathrm{m}^{3}$ of concrete, and ecofriendly and low-cost bricks in which at least $10 \%$ of the sand will be replaced by recovered ceramic materials (including, for example, aggregate or glass sand) [11]. It is worth to pay more attention to the above-mentioned cullet which is obtained from used bottles or other glass materials of everyday use. The cullet is used as a charge in glass furnaces and as a raw material for the production of glass fibers, insulating mats and boards, foam glass, glass balls, and grits for plasters and ceramic masses. The analyses are still carried out within the scope of developing the possibility to use cullet in the process of low-clinker cement production, the characteristics of which correspond well to the idea of a closed-circle economy in the European construction industry [12-14].

According to Lafarge Holcim, glass additives help increase the fluidity of materials (currently mainly cement), making it easier to fill gaps in the construction of buildings and civil engineering structures. In tests, it was found that the addition of $3 \%$ waste glass to a cement sample was sufficient to increase the fluidity of the material being modified. Further increase in the proportion of glass in the sample further improves the achieved fluidity parameters, but with the increase of this substrate in the raw material mass, the porosity, strength and, consequently, the durability of the new material must be controlled [15,16]. According to the Cement Manufacturers Association, the demand for cullet in the modification of building materials may increase in Poland from 21.6 million tons in 2017 to 22.8 million in 2020 and beyond. A similar trend is also occurring globallyin 2011, the value of the global cement market was $\$ 237$ million, while in 2016 it was $\$ 394$ million. There is also an increasing demand from the global market related to the production of eco-friendly cement additives such as fly ash, slag, and silica fume [17].

Cullet from household and laboratory glassware is used in the production of porous vitreous and glass-like materials. Materials of this type are obtained by the method used in special ceramics, which consists in sintering glass powders with blowing agents in the form of organic substances (sucrose, polymer sponge) and inorganic salts (e.g., $\mathrm{Na}_{2} \mathrm{SO}_{4}$ ), which are removed by combustion or extraction. Materials obtained by this method are used as filtration membranes for food industry, ceramics, biotechnology, and wastewater treatment [18-20]. Appropriate management of recycled materials including optimal use of glass components and further reduction of $\mathrm{CO}_{2}$ emissions by about $40 \%$ in 2030 is a priority for cement and concrete producers. As part of this experiment, the so-called road map presented on May 12, 2020 by the European Cement Industry Association CEMBUREAU was created. In 2013, the European cement sector presented an ambitious goal that showed the possibility of reducing $\mathrm{CO}_{2}$ emissions by $32 \%$ by 2030 and by $80 \%$ in 2050 [21]. Therefore, the main point of this paper is to analyze the porous structure of autoclaved materials modified with glass sand (GS) in terms of economy and sustainable construction. This work is also a continuation of the research started in the article "A Sustainable Autoclaved Material Made of Glass Sand" [22], on the durability of autoclaved materials modified with glass sand, in which, however, research on the porous structure of the tested materials was not included.

\section{Materials and Methods}

The research and the presented tests were performed based on the CEN standards: PNEN 772-13: 2001, CEN. PN-EN 1996-2, CEN. PN-EN 771-2, and PN-EN 1936:2010 [23-26].

The materials tested are products made from natural components ( $90 \%$ of sand, $7 \%$ of lime, and around 3\% of water) under hydrothermal conditions (increased pressure 
$(1.6 \mathrm{MPa})$ and temperature $\left(200^{\circ} \mathrm{C}\right)$, bricks produced in autoclaves). The main aspect of the study was to determine the extent, size, and volume of the porous space in the silicate material modified by glass sand (GS). To the modified silicate mass (silicate mass it means: quartz sand or glass sand $+\mathrm{CaO}+\mathrm{H}_{2} \mathrm{O}$ ) was added $90 \%$ glass sand (GS) completely eliminating the proportion of quartz sand $\left(\mathrm{SiO}_{2}\right.$ and usually $50-60 \%$ of the $90 \% \mathrm{SiO}_{2}$ is the sand with a grain size between $(0-0.5) \mathrm{mm}$, and the other $30-40 \%$ of the $90 \% \mathrm{SiO}_{2}$ is the sand with a grain size $(0.5-20 \mathrm{~mm}))$. For the modifications of the reference bricks were used: quartz industrial sand $\left(\mathrm{SiO}_{2}\right)$ and modified bricks Glass Sand (GS < 80-160 > $\left.\mu \mathrm{m}\right)$. Other components of the mass remained unchanged.

The research started in the article "A Sustainable Autoclaved Material Made of Glass Sand" [22] showed that during the modification of the silicate mass with $90 \%$ glass sand, the compressive strength is $20.23 \mathrm{MPa}$, and the volume density is $2.3 \mathrm{~kg} / \mathrm{dm}^{3}$ (Table 1). The hydration of lime reached a temperature is around $42{ }^{\circ} \mathrm{C}$ for the modification of sand-lime mass by $90 \%$ GS during the hydration of lime. The hydration temperature of the lime in the presence of quartz sand is typically around $86{ }^{\circ} \mathrm{C}$. This is one of the differences in the production of both types of bricks. Figure 1 shows how silicate brick is made under industrial conditions [22].

Table 1. Plan of the experiment (fragment of the research). Traditional bricks with quartz sand and bricks modified by glass sand [22].

\begin{tabular}{cccc}
\hline Quartz Sand (\%) & Glass Sand (\%) & $\begin{array}{c}\text { Compressive } \\
\text { Strength (MPa) }\end{array}$ & $\begin{array}{c}\text { Bulk Density } \\
\mathbf{( k g / \mathbf { d m } ^ { 3 } )}\end{array}$ \\
\hline 90 & 0 & 5.25 & 1.92 \\
50 & 40 & 14.13 & 2.18 \\
0 & 90 & 20.23 & 2.30 \\
\hline
\end{tabular}

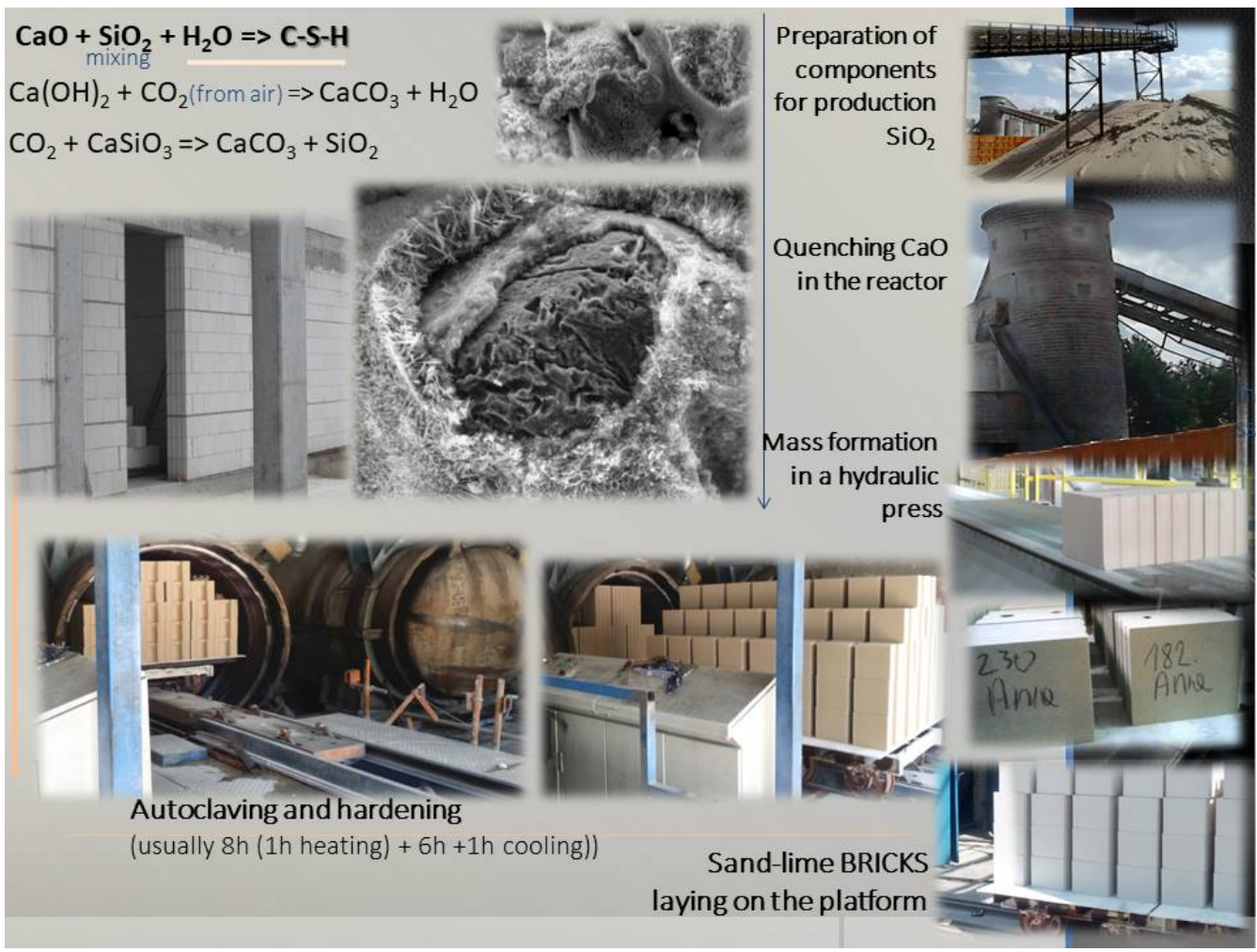

Figure 1. Production flow of traditional sand-lime bricks.

After mixing the substrates of silicate mass (sand, lime, water and modifiers) the mix is placed in steel reactors for $4 \mathrm{~h}$. The temperature inside of the reactors it is around 
$60-80{ }^{\circ} \mathrm{C}$. The mixture is directed to the press, in which it is compressed at a pressure around 15-20 MPa, and subsequently molded under pressure into blocks of the assumed brick size and shape. The final stage is placing the bricks in an autoclave. During the 6-12 h (on average $8 \mathrm{~h}$ in industrial conditions and $5 \mathrm{~h}$ in laboratory conditions) of autoclaving (Figure 2) the $\mathrm{CaO}$ reacts chemically with $\mathrm{SiO}_{2}$ and the mixture undergoes the process of recrystallization [18]. Water in the amount of $7-9 \%$ of the mass supplements the mixture (for $250 \mathrm{~kg}$ sand-lime mass one expects about $18-20$ liters of water, which is $7.2-8 \%$ of the product weight) [27].

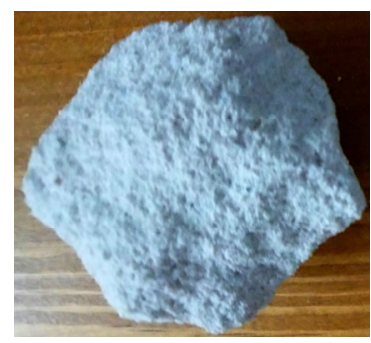

(a)

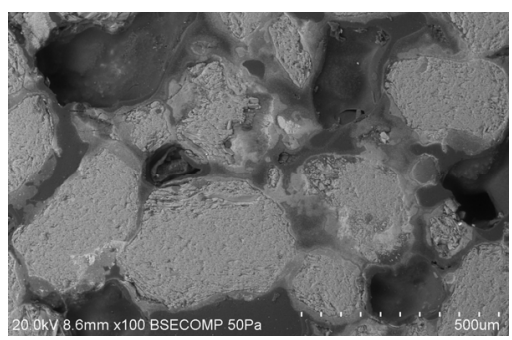

(b)

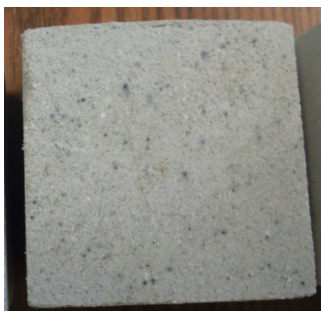

(c)

Figure 2. Fragment of the surface of bricks. (a,b) Fragment of the surface of traditional brick made with $90 \mathrm{wt} \%$ quartz sand; (c) fragment of the surface of brick modified by $90 \mathrm{wt} \%$ recycled glass sand (GS).

Material structure tests were also performed based on the following tests:

- Porosimetry (mercury porosimeter, SYL and ANT Instruments, Silesian Voivodeship, Poland), micrometrics (AutoPore IV, Micromeritics, Norcross, GA, USA), and pore size distribution analysis by the MIP method (Mercury Intrusion Porosimetry/Mercury Porosimetry Method).

- $\quad$ Phase structure study based on X-ray diffraction analysis (XRD, Empyrean PANalytical diffractometer using Ka radiation from a $\mathrm{Cu}$ anode, Malvern Panalytical, Malvern, UK) and microstructure by scanning electron microscopy (scanning electron microscope Quanta FEG 250 FEI Company and IROL 5400, FEI Company, Hillsboro, OR, United States);

- $\quad$ X-Ray Fluorescence (XRF, PANalytical instrument, Malvern Panalytical, Malvern, UK).

- Micro CT analysis - Industrial computed tomography (Nikon XT H 225 ST microscope, University of Technology in Kielce, Poland).

- Calorimetry - measurement of heat generated by chemical reactions and various physical processes.

\section{Results}

This research and the presented tests were performed based on the CEN standards: PN-EN 772-13: 2001, CEN. PN-EN 1996-2, CEN. PN-EN 771-2, and PN-EN 1936:2010.

An important aspect of the study was to perform XRF analysis (Table 2; oxide and elemental composition) of the materials analyzed. Tested materials consist of a low binder content ( $7 \%$ lime by mass) and are abundant in silica up to $90 \%$ by mass and which were modified with broken amorphous glass (GS). Glass sand is characterized by a high content of sodium compounds [22]. The presence of aluminum in the sample may affect the swelling of the material, therefore, an important aspect of the test is to perform the elemental composition analysis to complete the data on the amount of aluminum compounds in the tested material. Aluminum also influences the synthesis of the tobermorite phase, which is the dominant phase in the microstructure of silicate brick. 
Table 2. XRF analysis of the bricks (traditional and modified by glass sand). Initial sample weight (g): 1.000 and weight after pressing $(\mathrm{g}): 3.000$ of the samples.

\begin{tabular}{cccc}
\hline & Reference Bricks & Bricks with GS & Unit \\
\cline { 2 - 3 } Formula & Concentration & Concentration & $\%$ \\
\cline { 2 - 2 } & 66.101 & 48.279 & $\%$ \\
$\mathrm{SiO}_{2}$ & 31.007 & 38.771 & $\%$ \\
$\mathrm{Fe}_{2} \mathrm{O}_{3}$ & 1.096 & 2.014 & $\%$ \\
$\mathrm{SO}_{3}$ & 0.196 & 0.333 & $\%$ \\
$\mathrm{Al}_{2} \mathrm{O}_{3}$ & 0.733 & 1.223 & $\%$ \\
$\mathrm{MgO}$ & 0.203 & 0.457 & $\%$ \\
$\mathrm{Na}_{2} \mathrm{O}$ & 0.271 & 5.826 & $\%$ \\
$\mathrm{~K}_{2} \mathrm{O}$ & 0.15 & 1.199 & $\%$ \\
$\mathrm{SrO}$ & 0.049 & 0.143 & $\%$ \\
$\mathrm{ZrO}$ & 0.091 & 0.109 & $\%$ \\
$\mathrm{TiO}$ & - & 0.371 & $\%$ \\
$\mathrm{P}_{2} \mathrm{O}$ & - & 0.112 & $\%$ \\
$\mathrm{MnO}$ & - & 0.151 & $\%$ \\
$\mathrm{ZnO}$ & - & 0.21 & $\%$ \\
$\mathrm{Rb}$ & - & 0.021 & $\%$ \\
$\mathrm{CuO}$ & - & 0.069 & $\%$ \\
$\mathrm{BaO}$ & - & 0.084 & $\%$ \\
$\mathrm{PbO}$ & - & 0.23 & $\%$ \\
$\mathrm{Cl}$ & - & 0.109 & $\%$ \\
\hline
\end{tabular}

* The test takes into account the percentage by weight of the material sent for the test.

\section{Structural and Microstructural Properties}

In order to adequately analyze the porous structure of glass sand modified autoclaved materials, microscopic studies were necessary. Since autoclaved products are formed from a binder mixture (lime) in the presence of sand and water, a lime hydration process occurs. This process may be incomplete in the first stage, which depends on the quality, moisture content and quantity of the substrates forming the raw material mass and on the external environmental conditions. Therefore, a calorimetric measurement was carried out in order to check possible reactions that could occur as a result of temperature changes (because the temperature of lime hydration in the presence of quartz sand is typically about $86^{\circ} \mathrm{C}$, while the temperature of lime hydration in the presence of glass sand is about $42{ }^{\circ} \mathrm{C}$. Despite this temperature difference in the binder hydration process, this test showed that the tested samples had stable and almost identical diagrams). The calorimetric analysis showed no significant changes when the sample was heated. Three measurements: PR1-measurement of a traditional sample, PR2 - measurement of a sample with $50 \%$ GS and $50 \% \mathrm{SiO}_{2}$ and PR3 - measurement of a sample modified with $90 \%$ GS (Figure 3).

Calorimetric studies are important due to the fact that autoclaved products are formed by hydrothermal treatment. Heat is released during the hydration process, while the amount of binder (lime) provides the basis for information on which of the hydrated calcium silicates will form (for example: tobermorite or jennite). The basic phase that is formed in autoclaved materials is tobermorite. The C-S-H phase here (as opposed to concretes) is the deficit phase. The C-S-H phase is a thermodynamically stable phase up to a temperature of about $30^{\circ} \mathrm{C}$, and as a result of physical changes (e.g., temperature) it crystallizes. The XRD study were performed to determine the presence of each phase. The XRD phase analysis of the traditional brick (Figure 4) and brick modified by sand glass samples (Figure 5) were performed in the $10-70^{\circ} 2 \theta$ range [22,28-30]. 


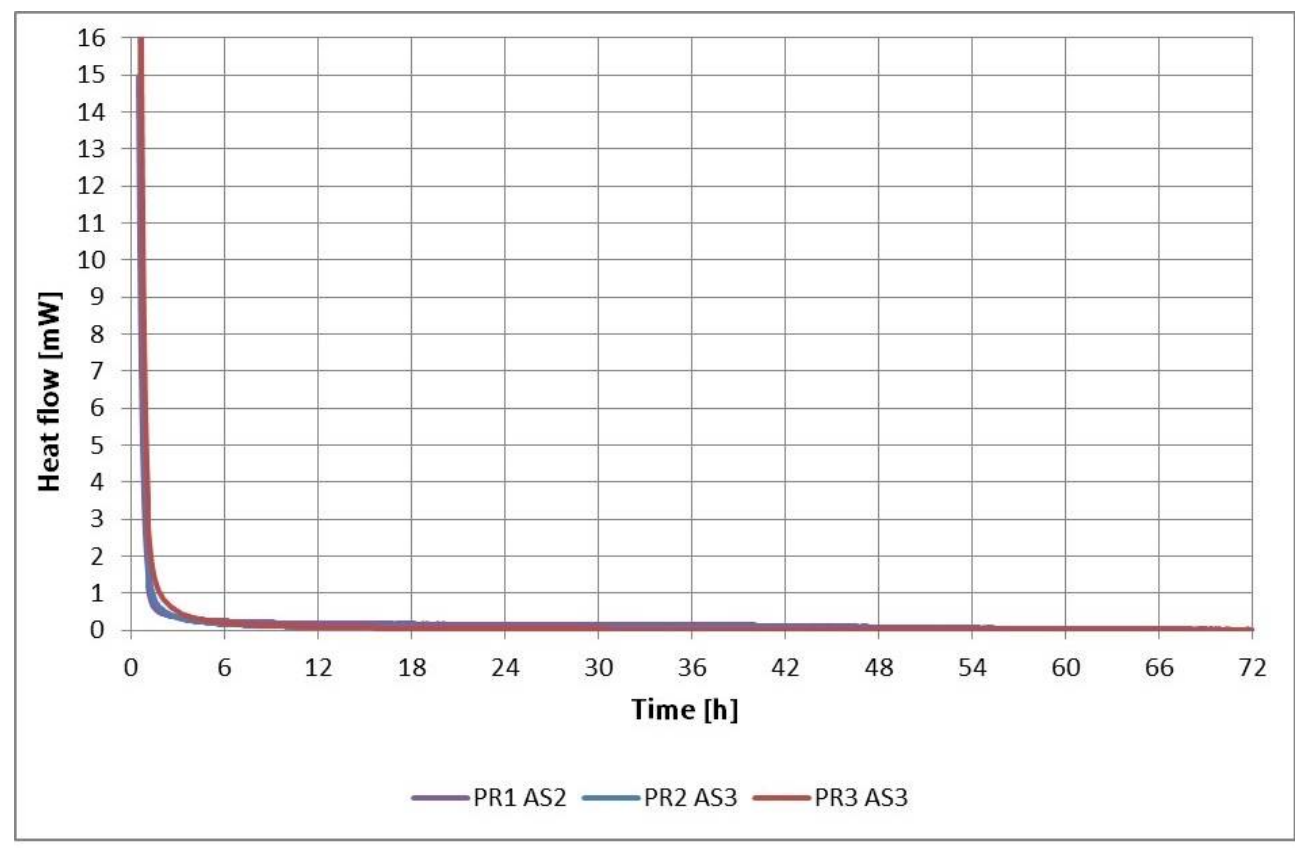

Figure 3. Heat flow study in autoclaved materials.

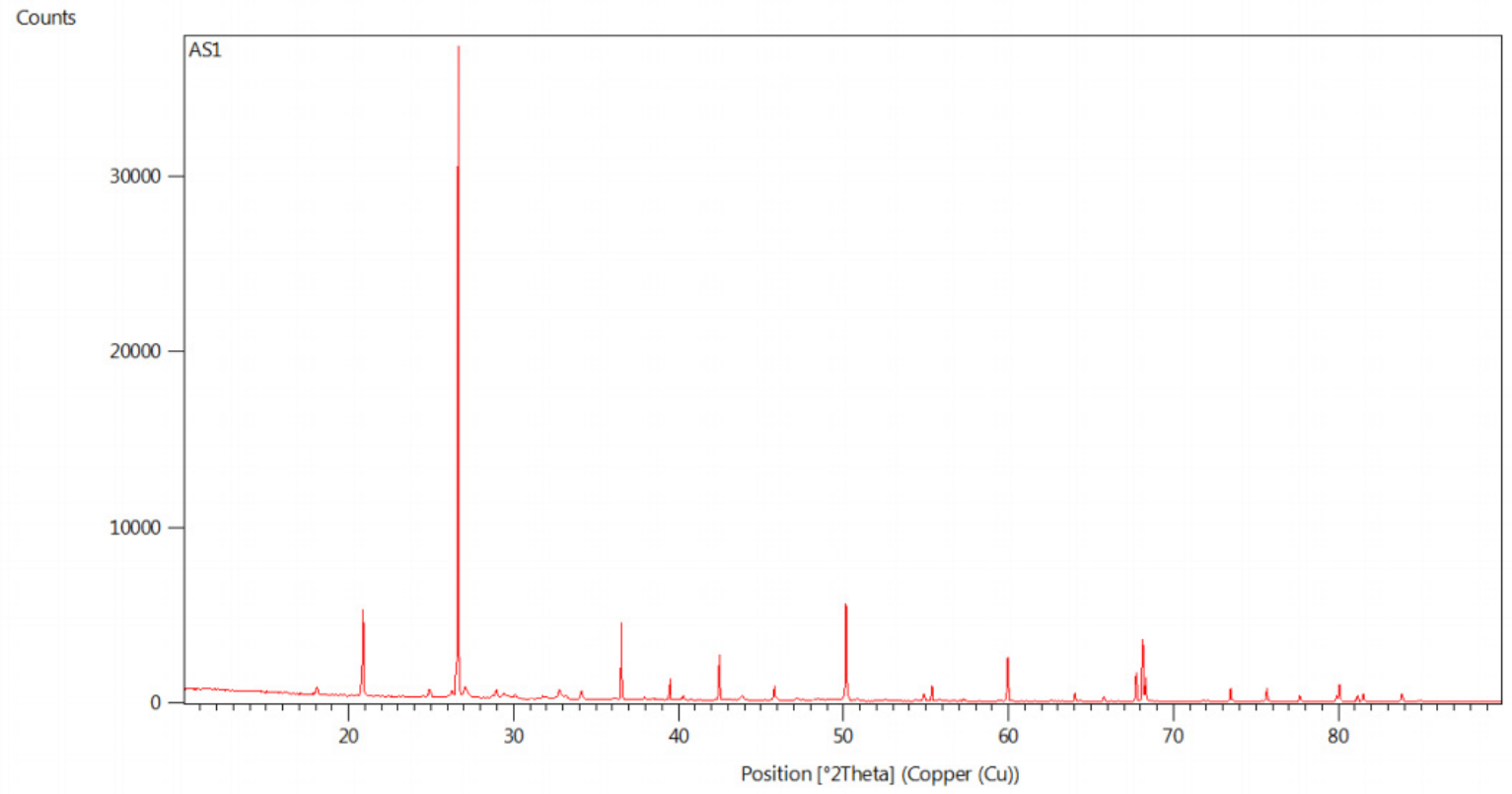

Figure 4. XRD analysis of reference sample.

The XRD analysis of the reference brick provided for the tests showed the presence of mainly sand peaks (quartz-the highest), it is related to the fact that the quartz sand has a crystalline, ordered structure. Glass sand, on the other hand, has an amorphous (disordered) structure and is thermodynamically metastable (changes its properties under the influence of changing environmental conditions (i.e., temperature and pressure). A brick modified with amorphous glass sand crystallizes as a function of time and temperature. Due to the presence of sodium in the material, this crystallization tends towards gyrilite and/or natrolite (the readability of these phases depends on the degree of crystallization and the database of research devices). 


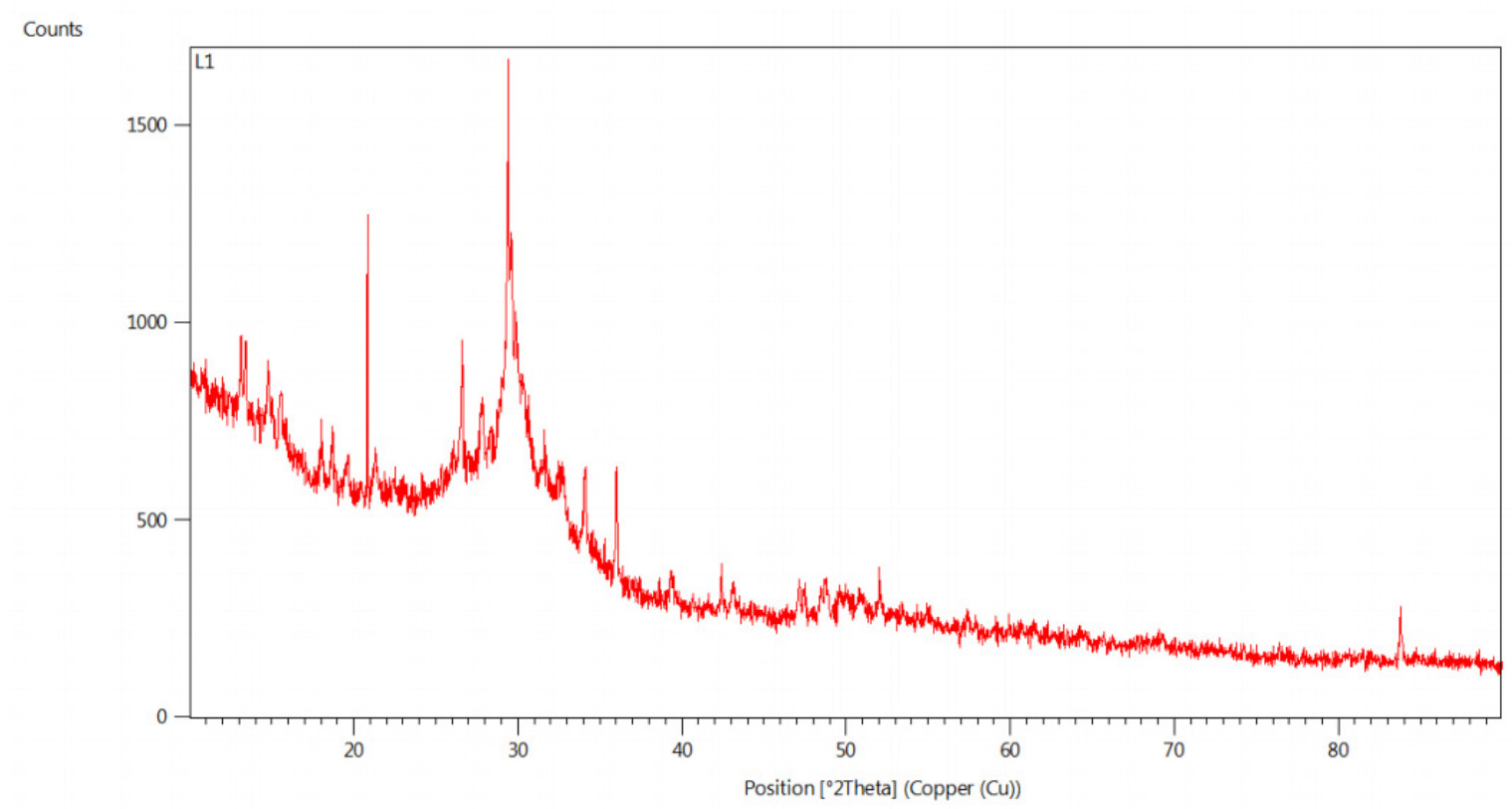

Figure 5. XRD analysis of sample modified by glass sand.

In order to visualize the arrangement of pores in the studied materials, the studies were performed: SEM (scanning electron microscope) and micro-CT analysis (tomography).

Computed tomography (Nikon XT H 225 ST) showed the presence of pores at about $20 \%$, Figures 6-8) at a density of $2.21 \mathrm{~kg} / \mathrm{dm}^{3}$ for the bricks modified by $90 \%$ GS. Density tests were performed using a QUANTACHROME ULTRAPYC 1200e helium pycnometer on irregularly shaped samples weighing approximately 10-25 grams. The helium pycnometer used in this study is a fully automated piece of equipment.

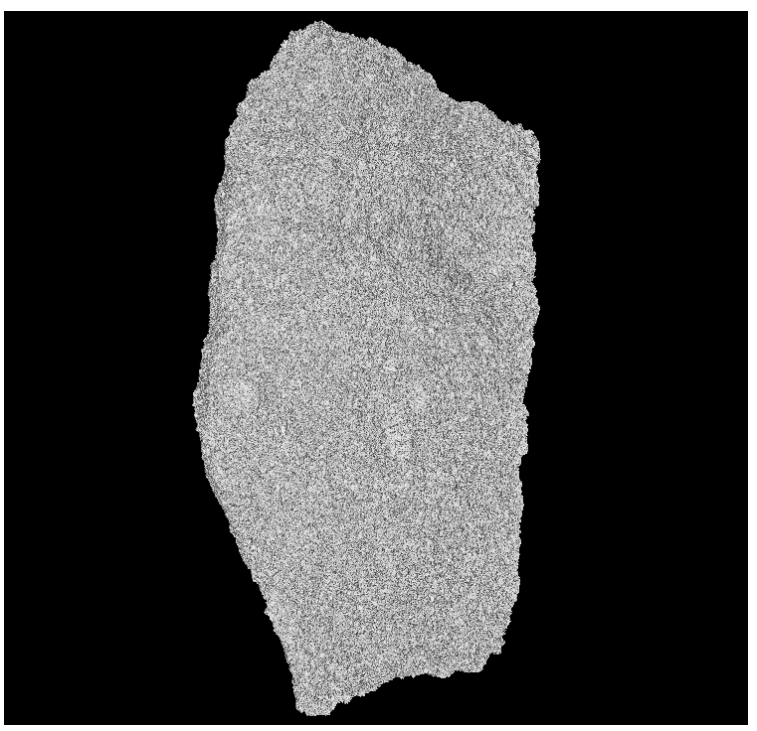

(a)

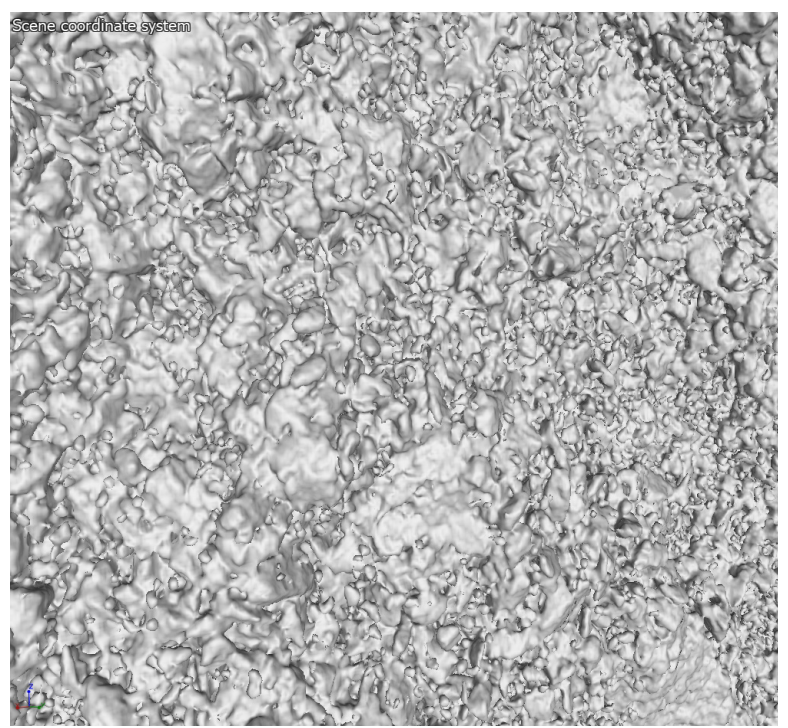

(b)

Figure 6. (a) computed tomography image of brick modified by glass sand; (b) 3D analysis of the examined micro-area. 


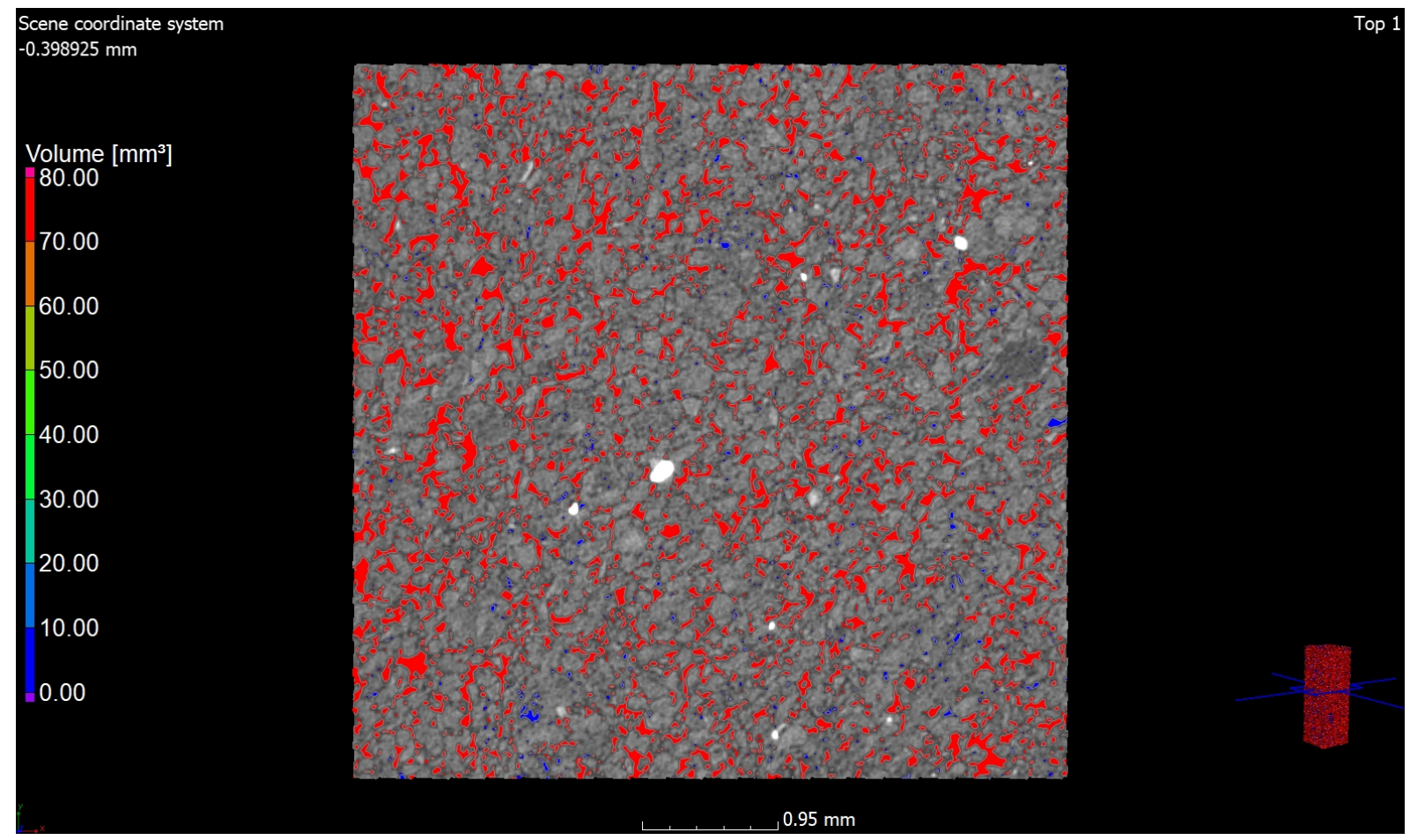

Figure 7. Micro-CT analysis. Amount of air voids (20\%) in silicate brick modified with glass sand.

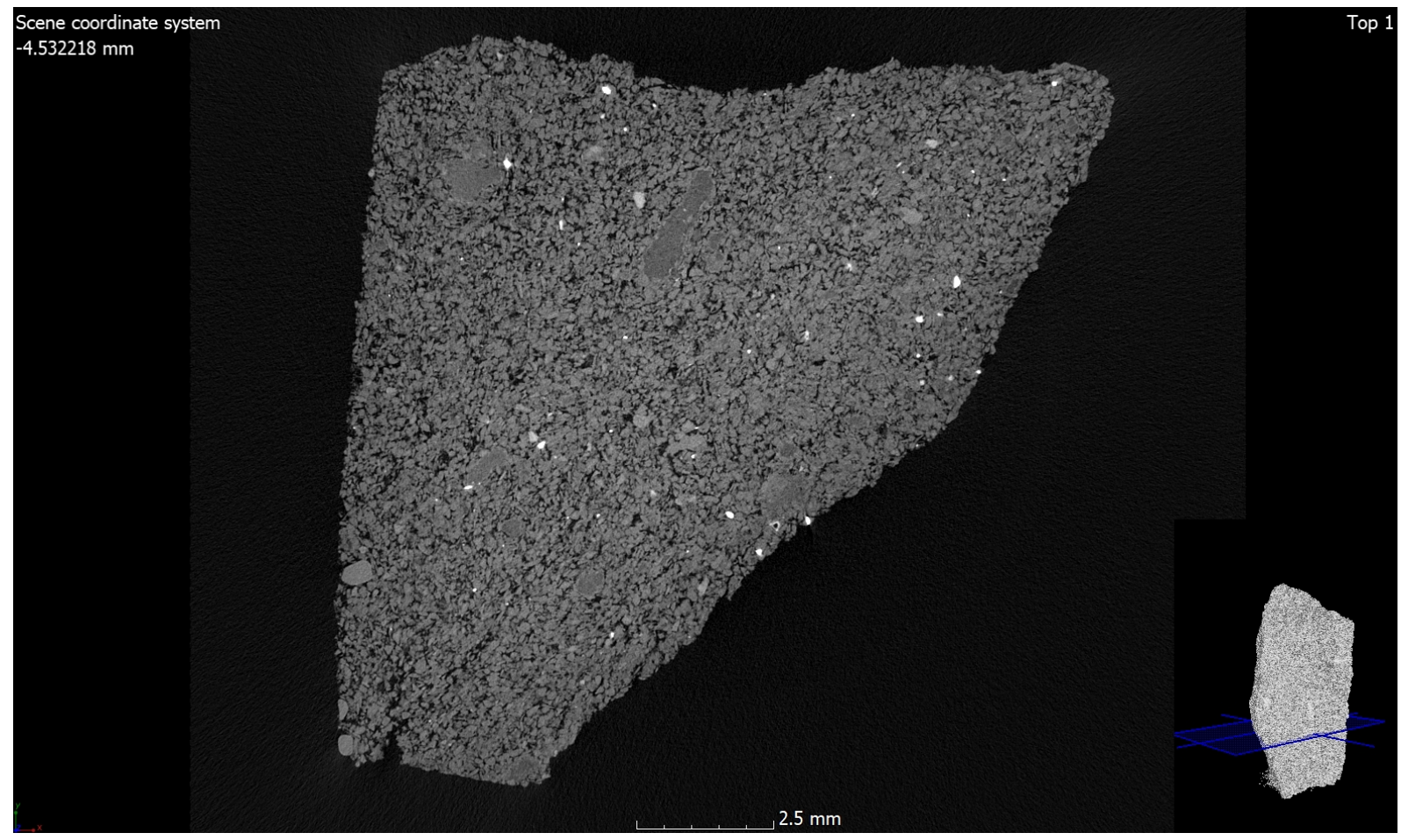

Figure 8. Micro-CT analysis. Cross section through the brick modified by glass sand. Porous structure analysis.

The image of a sample of a brick modified with glass sand was obtained by computed tomography and its cross-section, where it is possible to distinguish cracks, pores, and air voids (the amount of air content in the analyzed cross-section colors are according to the scale, Figures 6 and 7). 
Micro-CT analysis showed the total pore content of the sample to be $20 \%$. The figure shows a picture of the distribution and intensity of pores depending on their size and shape. The scale on the left shows the proportion of pores of a specific size in the sample.

The scanning electron microscopy (SEM) aimed to show the image of the glass sand grain arrangement with respect to the binder (Figures 9 and 10), the image of the pore size, the characteristics of the phases formed (tobermorite, gyrolite, natrolite). Due to the presence of sodium compounds (Figures 11 and 12) and the possibility of formation at high temperatures, gyrolite and natrolite can be formed in addition to the characteristic tobermorite phase in the materials studied.

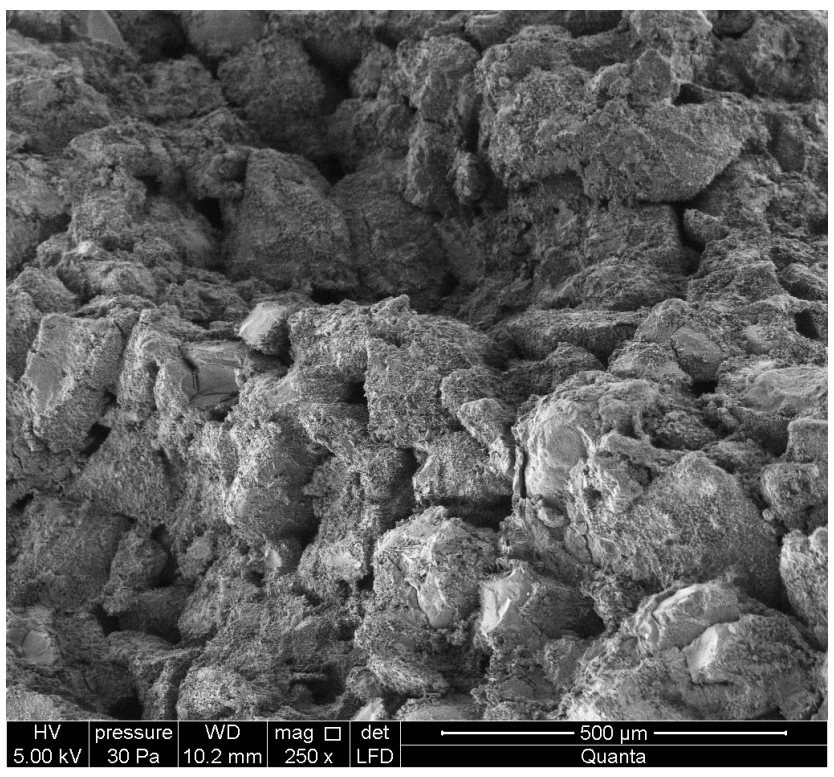

Figure 9. Microstructure (SEM image) of autoclaved brick modified by glass sand, $250 \times$ magnification.

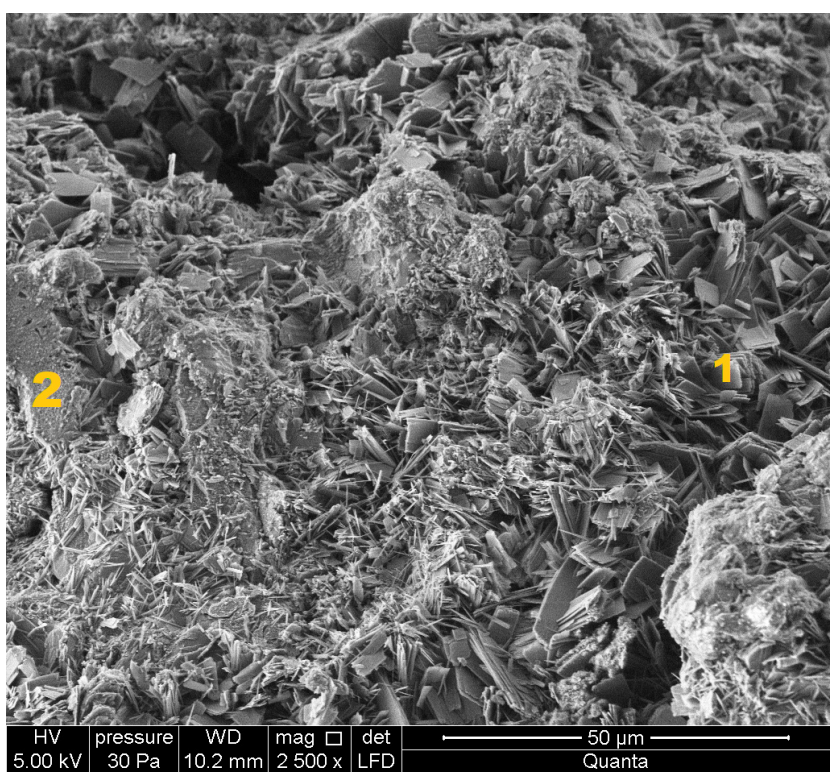

Figure 10. Microstructure (SEM image) of autoclaved brick modified by glass sand, $2500 \times$ magnification. 


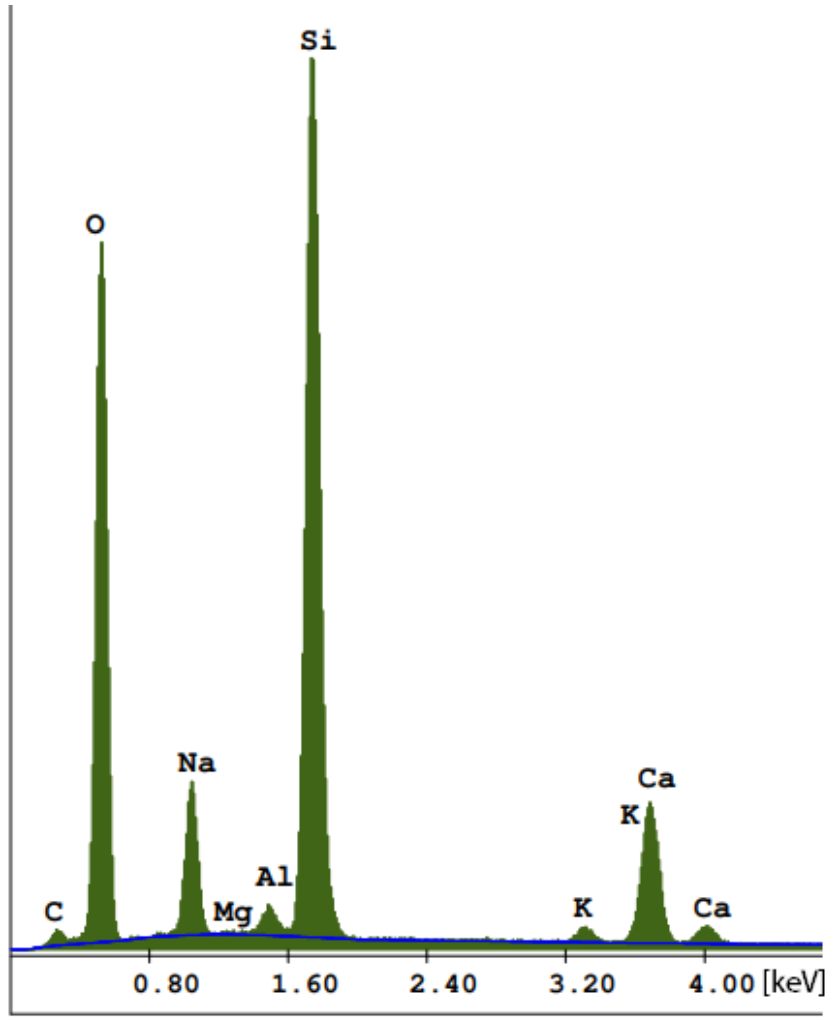

Figure 11. EDS spectrum at point 1 .

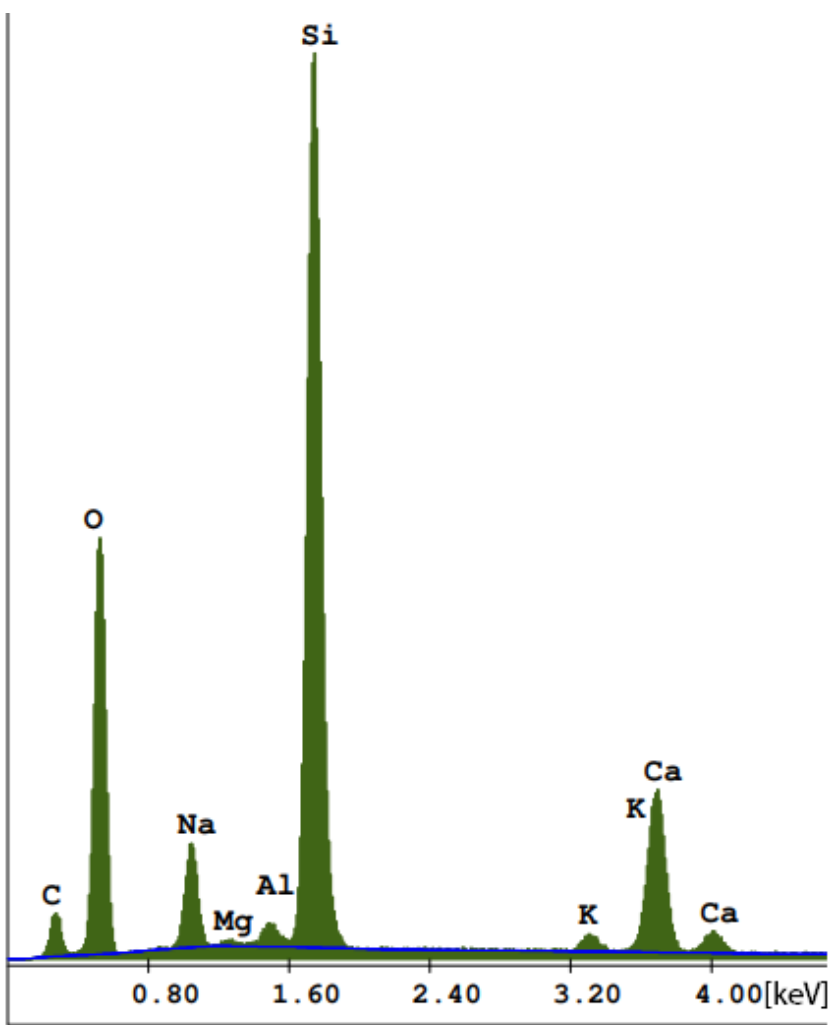

Figure 12. EDS spectrum at point 2.

The elemental analysis at test points 1 and 2 (Figures 13 and 14) on the scanning electron microscope is shown below. 


\begin{tabular}{|c|c|c|c|c|c|c|}
\hline Element & Wt $\%$ & At $\%$ & K-Ratio & $\mathrm{Z}$ & A & $\mathrm{F}$ \\
\hline$C \mathrm{~K}$ & 2.59 & 4.37 & 0.0042 & 1.0420 & 0.1545 & 1.0006 \\
\hline O K & 48.12 & 61.00 & 0.1433 & 1.0245 & 0.2906 & 1.0004 \\
\hline $\mathrm{NaK}$ & 7.07 & 6.23 & 0.0299 & 0.9589 & 0.4391 & 1.0037 \\
\hline $\mathrm{MgK}$ & 0.11 & 0.10 & 0.0006 & 0.9830 & 0.5360 & 1.0072 \\
\hline AlK & 1.03 & 0.78 & 0.0068 & 0.9541 & 0.6790 & 1.0135 \\
\hline SiK & 31.16 & 22.50 & 0.2404 & 0.9819 & 0.7847 & 1.0013 \\
\hline K K & 0.86 & 0.45 & 0.0075 & 0.9310 & 0.9163 & 1.0147 \\
\hline $\mathrm{CaK}$ & 9.05 & 4.58 & 0.0813 & 0.9531 & 0.9426 & 1.0000 \\
\hline Total & 100.00 & 100.00 & & & & \\
\hline
\end{tabular}

Figure 13. Elemental analysis of a fragment of GS modified brick in point 1.

\begin{tabular}{|c|c|c|c|c|c|c|}
\hline Element & Wt $\%$ & At $\%$ & K-Ratio & Z & $\mathrm{A}$ & $\mathrm{F}$ \\
\hline $\mathrm{C} \mathrm{K}$ & 8.41 & 14.23 & 0.0134 & 1.0427 & 0.1524 & 1.0005 \\
\hline O K & 38.87 & 49.42 & 0.0953 & 1.0252 & 0.2390 & 1.0004 \\
\hline $\mathrm{NaK}$ & 5.29 & 4.68 & 0.0232 & 0.9595 & 0.4555 & 1.0041 \\
\hline $\mathrm{MgK}$ & 0.27 & 0.23 & 0.0015 & 0.9836 & 0.5661 & 1.0083 \\
\hline $\mathrm{AlK}$ & 0.92 & 0.69 & 0.0063 & 0.9547 & 0.7054 & 1.0156 \\
\hline SiK & 33.51 & 24.27 & 0.2663 & 0.9825 & 0.8073 & 1.0017 \\
\hline K K & 1.08 & 0.56 & 0.0094 & 0.9318 & 0.9146 & 1.0185 \\
\hline $\mathrm{CaK}$ & 11.64 & 5.91 & 0.1044 & 0.9539 & 0.9403 & 1.0000 \\
\hline Total & 100.00 & 100.00 & & & & \\
\hline
\end{tabular}

Figure 14. Elemental analysis of a fragment of GS modified brick in point 2.

As mentioned in the article, the silicate mass modifier in the form of glass sand may be a favorable solution in terms of durability of the modified materials due to its amorphous structure (similar to the amorphous C-S-H phase, which constitutes $60-70 \%$ of the concrete structure). However, amorphous materials crystallize, therefore, the degree and directions of crystallization of the modified materials should be investigated and controlled. From the XRF analysis (knowledge of information on the oxide and elemental composition) and the composition of the silicate mass, and further on the production method and exploitation temperature, it can be concluded in which direction the crystallization of the material can be expected. Due to the presence of sodium in the material, this crystallization tends towards gyrilite and/or natrolite (the formations visible in point 1 in the photo Figure 10). Figures 11 and 12 show the qualitative elemental analysis at the tested points. Therefore, the presence of an aluminum peak (Al) informs about the possibility of synthesizing the tobermorite phase in the analyzed sample.

The cell is calibrated and cleaned of any deposits before the measurement. The measurement is performed automatically after entering the necessary information, such as mass of the test sample and number of repetitions. One result consists of five individual density measurements taken one after the other. As a result, the density of the material is the average of five density measurements taken automatically under constant assumptions and the same temperature conditions. For the porosimetry tests (Figures 15 and 16), the samples were sequentially placed in the low pressure port where they were evacuated to $2.66 \mathrm{~Pa}$ and flooded with mercury at $0.035 \mathrm{MPa}$. 


\begin{tabular}{|c|c|}
\hline \multicolumn{2}{|c|}{ Low Pressure: } \\
\hline Evacuation Pressure: & $50 \mu \mathrm{mHg}$ \\
\hline Evacuation Time: & 5 mins \\
\hline Mercury Filling Pressure: & 0.53 psia \\
\hline Equilibration Time: & 10 secs \\
\hline Maximum Intrusion Volume: & $0.050 \mathrm{~mL} / \mathrm{g}$ \\
\hline \multicolumn{2}{|c|}{ High Pressure: } \\
\hline $\begin{array}{l}\text { Equilibration Time: } \\
\text { Maximum Intrusion Volume: }\end{array}$ & $\begin{array}{r}10 \mathrm{secs} \\
0.050 \mathrm{~mL} / \mathrm{g}\end{array}$ \\
\hline \multicolumn{2}{|c|}{ Blank Correction by Formula } \\
\hline \multicolumn{2}{|c|}{ Intrusion Data Summary } \\
\hline Total Intrusion Volume = & $0.2178 \mathrm{~mL} / \mathrm{g}$ \\
\hline Total Pore Area = & $12.780 \mathrm{~m}^{2} / \mathrm{g}$ \\
\hline Median Pore Diameter (Volume) = & $1.4933 \mu \mathrm{m}$ \\
\hline Median Pore Diameter $($ Area $)=$ & $0.0133 \mu \mathrm{m}$ \\
\hline Average Pore Diameter $(4 \mathrm{~V} / \mathrm{A})=$ & $0.0682 \mu \mathrm{m}$ \\
\hline Bulk Density at 0.53 psia $=$ & $1.6289 \mathrm{~g} / \mathrm{mL}$ \\
\hline Apparent (skeletal) Density = & $2.5246 \mathrm{~g} / \mathrm{mL}$ \\
\hline Porosity = & $35.4770 \%$ \\
\hline Stem Volume Used $=$ & $32 \%$ \\
\hline
\end{tabular}

Figure 15. Porosimetry test parameters (pore volume of the sample).

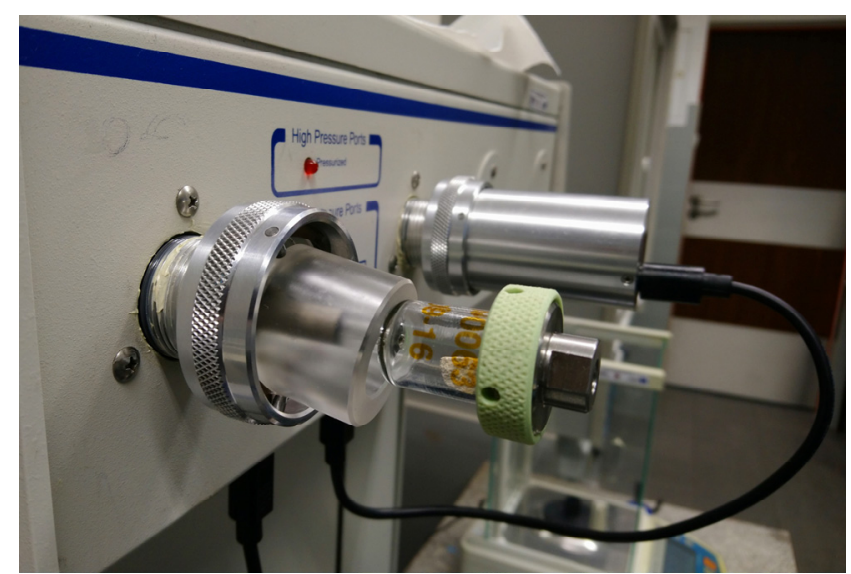

Figure 16. Porosimetric study of pore size in material (mercury porosimeter, SYL and ANT Instruments).

After returning to atmospheric pressure, the penetrometer was transferred to the highpressure port where the pressure was steadily raised to $420.58 \mathrm{MPa}$ with simultaneous measurement of the volume of the pressed mercury. At $10 \mathrm{MPa}$, the mercury fills pores with a diameter of $0.1 \mu \mathrm{m}$, and at $400 \mathrm{MPa}$ with a diameter of $0.003 \mu \mathrm{m}$. This level of pressures usually led to the destruction of some parts of the tested material, thus that the distribution and volume of the pores, as well as their geometry, can be disturbed and to some extent subject to measurement error. When analyzing the porosimetry results, it is important to remember that mercury is forced into pores $0.01 \mu \mathrm{m}$ in diameter and smaller at very high pressures over $100 \mathrm{MPa}$.

Therefore, if the pores are connected by narrow passages and the specimen material cannot withstand this loading, the pores are crushed before the mercury penetrates [23]. However, the possibility of injecting mercury into the bottle pores without particularly destroying the material structure must not be overlooked, in which case the calculation effect will be close to the actual one. As a result, the pore size distribution (Figures 17 and 18) calculated from the MIP (Mercury Intrusion Porosimetry) data will be incorrect. When we deal with large pores, with diameters around $1 \mu \mathrm{m}$, mercury is injected into them at a pressure of $1 \mathrm{MPa}$. A maximum pressure of $420 \mathrm{MPa}$ is needed to force the mercury into pores with diameters of $0.006 \mu \mathrm{m}$ [31]. High pressures can destroy the internal skeleton and open access to pores that were completely isolated under natural conditions. 


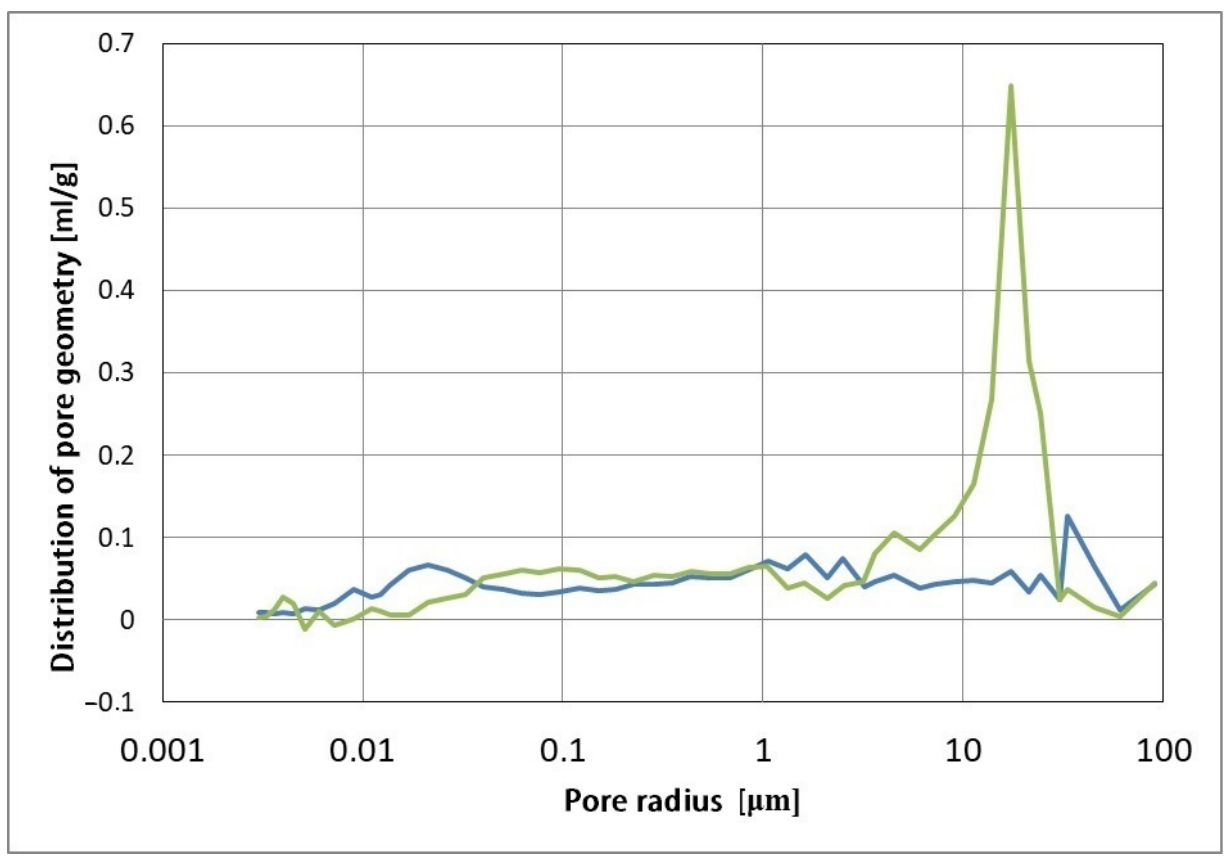

Figure 17. Pore size distribution in autoclaved brocks.

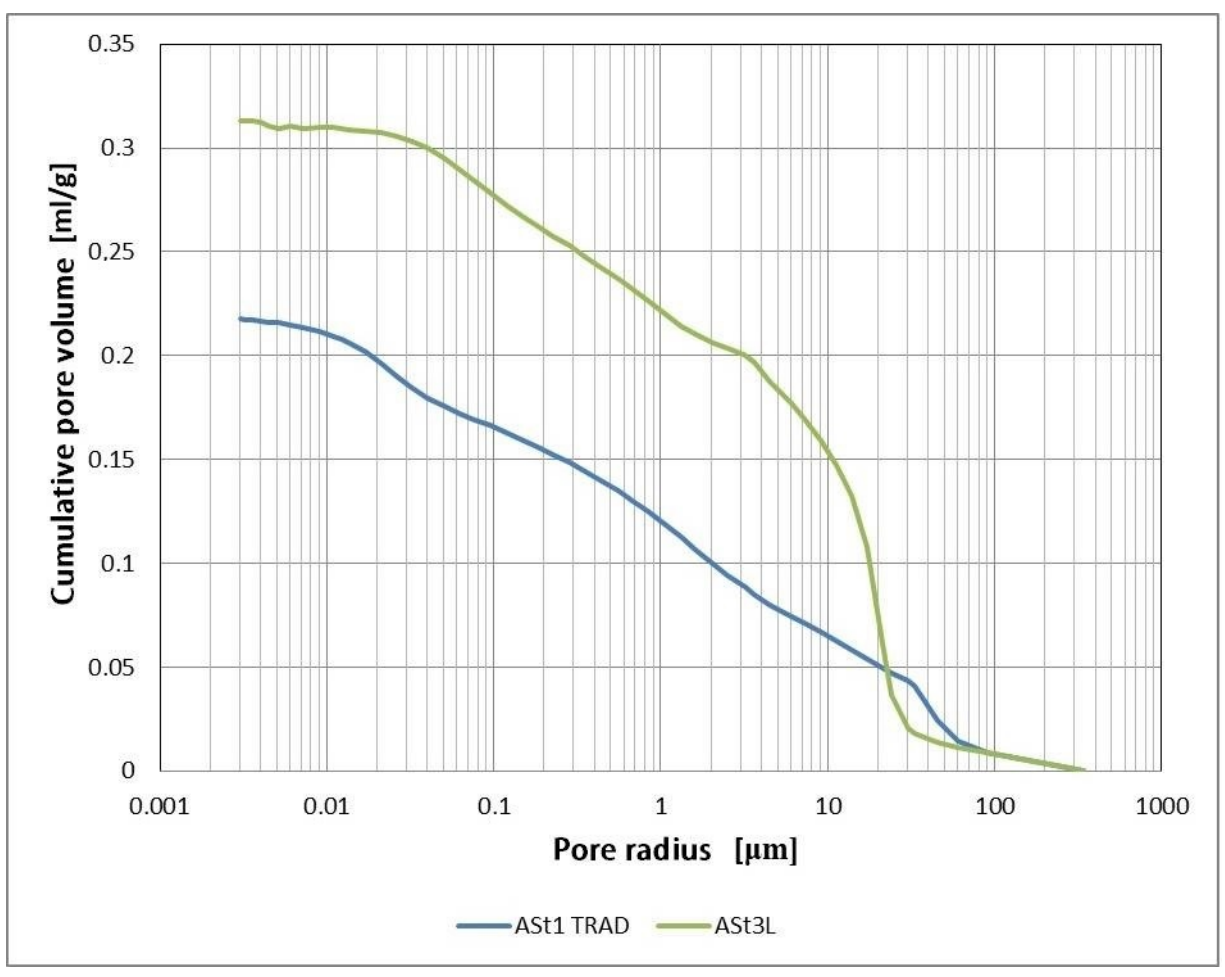

Figure 18. Cumulative pore volume in autoclaved bricks.

When analyzing the amount of mercury injected during the testing of the material, with the simultaneous increase in pressure, it is possible to determine the pore size distribution in the material (each pore diameter is assigned an appropriate inlet pressure).

Mercury is forced into pores of large diameter (approx. $1 \mu \mathrm{m}$ ) at a pressure of approx. $1 \mathrm{MPa}$. In pores with a diameter of about $0.006 \mu \mathrm{m}$, pressure is needed to the size of about $420 \mathrm{MPa}$. High pressures, unfortunately, can damage the internal skeleton of the tested material and, thus, change its internal structure (including microstructure) and cause the formation of new microcracks, gaps/channels, which may affect the test result. 
When analyzing the bulk density tests $\left(2.3 \mathrm{~kg} / \mathrm{dm}^{3}\right)$, the micro-CT analysis (about $20 \%$ of the pores content in the modified glass sand sample) and the porosimetry results), the tests seem to be consistent and at this stage indicate the appropriate durability of the material modified with glass cullet. The porosimetry test complements the micro-CT test. Both tests show that pores with a size of 1-20 $\mu \mathrm{m}$ have the largest share (highest intensity in Figure 7). The figure (Figure 19) shows that a large porous volume in the sample is made up of free spaces with a size of (0.1-50) $\mu \mathrm{m}$. The structure of the glass sand-modified material is homogeneous and compact, and the sand grains are well integrated with the binder, which is a high confidence of adequate durability of the material.

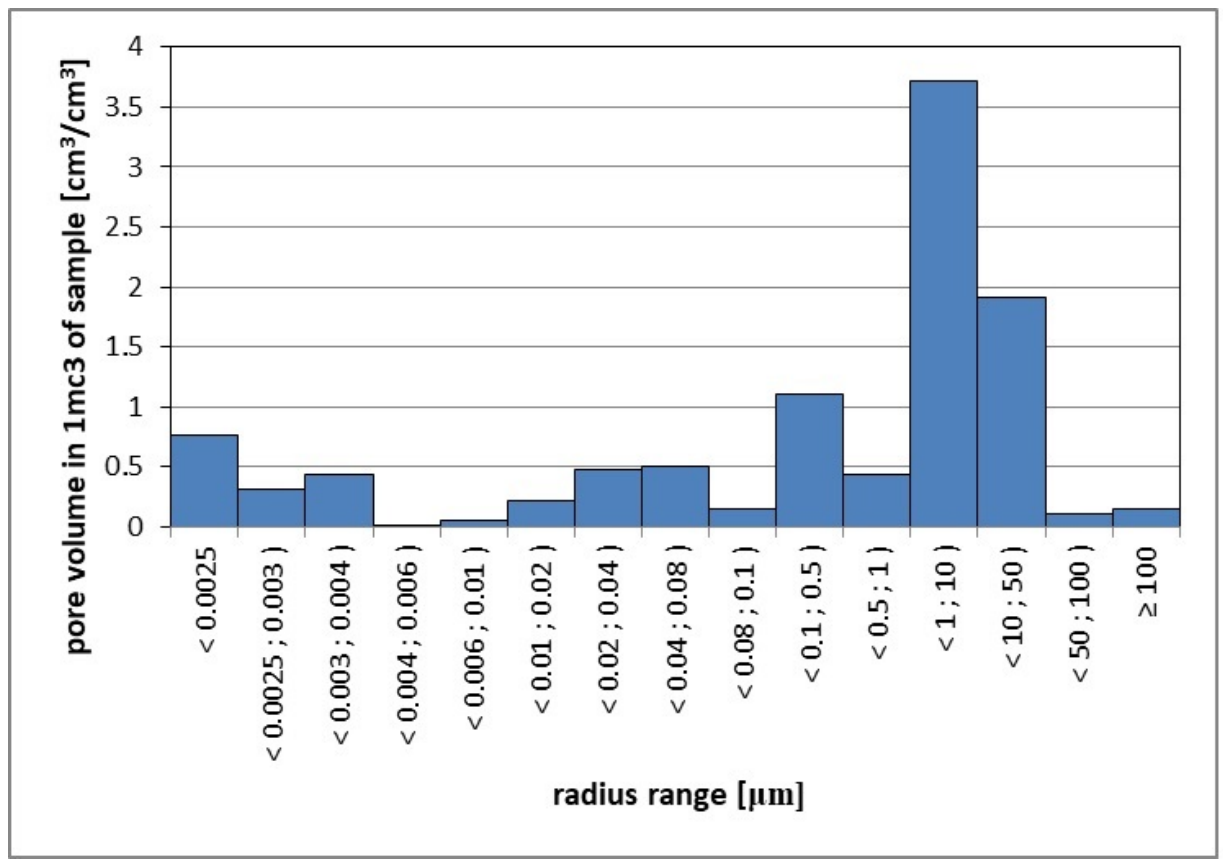

Figure 19. Pore volume in $1 \mathrm{~m}^{3}$ of the test sample.

\section{Discussion and Conclusions}

The porosimeter test for bricks modified by glass sand showed a large accumulation of pores in the size of $0.1-50 \mu \mathrm{m}$ than a traditional sample. This may indicate that the 'new' material is harder and more compact. The structure of the glass sand-modified material is homogeneous and compact, and the sand grains are well integrated with the binder, which is a high confidence of adequate durability of the material. The results show that the more glass sand, the better the resistance and density that may be achieved. The only disadvantage of modification by GS is that the impact of water and vapor on recycled glass in hydrothermal conditions has not been still recognized. In order to gain additional results on the subject of resistance, texture and durability of the examined material is needed to perform the next research being considered-on flexibility module and surface firmness using, for example, a calibrated Berkovich indenter. At the moment, microstructure investigations (SEM, micro-CT) showed a compact pore structure and allowed to determine the potential share of free spaces $(20 \%)$ in the material modified with glass sand (while maintaining the strength at 10-15 MPa and bulk density: $2.21 \mathrm{~kg} / \mathrm{dm}^{3}$ ). Pores with a diameter of 1-20 $\mu$ m occupy the largest space in the analyzed sample. As can be seen from the test description, the test may be subject to error, but the graphs (Figures 17 and 18) clearly show the contribution of more fine pores in the glass sand modified sample. A good direction for further research would be to determine the thermal and acoustic properties of materials formed as a result of the modification of silicate mass with glass sand. In addition, new phases with a higher degree of structural order are 
produced in the material modified in this way, which also affects the quantity, quality and shape of the free spaces created in this type of construction material.

Funding: This This article is part of a research activity entitled: Subsidy-Implementation of internal tests: Modification of construction products. The micro-CT analysis tomograph was performed on the Nikon XT H 225 ST (CENWIS, University of Technology in Kielce, PL).

Acknowledgments: The author would like to acknowledge to: Rector Zbigniew Koruba, Dean (WBA/CIA) Grzegorz Świt and Ryszard Dachowski from KUT University in Kielce (PL) and Maciej Sitarz, Magdalena Leśniak from AHG Univeristy in Cracow for cooperation and support and Karol Skowera and Magdalena Durlej from KUT Kielce (PL) for cooperation.

Conflicts of Interest: The authors declare no conflict of interest.

\section{References}

1. Charmas, B. Habilitation Self-Reference Zastosowanie Metod Termicznych i Kalorymetrycznych do Badania Wybranych Układów Porowatych; Uniwersytet Marii Curie-Skłodowskiej w Lublinie, Wydział Chemii, Zakład Metod Chromatograficznych: Lipiec, Poland, 2015.

2. Schober, G. Porosity in Autoclaved Aerated Concrete (AAC): A Review on Pore Structure, Types of Porosity, Measurement Methods and Effects of Porosity on Properties. In Proceedings of the 5th International Conference on Autoclaved Aerated Concrete, Bydgoszcz, Poland, 14-17 September 2011; pp. 39-43.

3. Isu, N.; Teramura, S.; Ishida, H.; Mitsuda, T. Mechanical Property Evolution during Autoclaving Process of Aerated Concrete Using Slag: II, Fracture Toughness and Microstructure. J. Am. Ceram. Soc. 2005, 77, 2093-2096. [CrossRef]

4. Korecký, T.; Keppert, M.; Maděra, J.; Černý, R. Water transport parameters of autoclaved aerated concrete: Experimental assessment of different modeling approaches. J. Build. Phys. 2015, 39, 170-188. [CrossRef]

5. Guglielmi, P.O.; Silva, W.R.L.; Repette, W.L.; Dachamir Hotza, D. Porosity and Mechanical Strength of an Autoclaved Clayey Cellular Concrete. In Advances in Civil Engineering 2010; Hindawi Publishing Corporation: London, UK, 2010; pp. 1-7. [CrossRef]

6. Rutkowska, G.; Kijanka, P. Analiza porównawcza wybranych cech technicznych cegieł pełnych na przykładach budynków jednorodzinnych. Acta Sci. Pol. Archit. 2010, 9, 35-44.

7. Autoclaved Aerated Concrete. Available online: https://www.solbet.pl/en/technical-parameters/ (accessed on 30 March 2021).

8. CEN. EN 771-4: Specification of Masonry Elements-Part 4: Concrete Blocks; European Committee for Standardization (CEN): Brussels, Belgium, 2011.

9. CELLULAR CONCRETE IS THE MOST POPULAR. Available online: https:/ / www.solbet.pl/en/cellular-concrete-is-th-e-mostpopular/ (accessed on 30 March 2021).

10. Mindess, S. Relation Between the Compressive Strength and Porosity of Autoclaved Calcium Silicate Hydrates. Presented at the 72nd Annual Meeting, The American Ceramic Society, Philadelphia, PA, USA, 4 May 1970. [CrossRef]

11. CEMBUREAU Roadmap 2020-2050. Available online: https://www.polskicement.pl/aktualnosci/cembureau-roadmap-2020-2 050-ograniczenie-emisji-co2-o-ok-40-na-koniec-dekady / (accessed on 11 February 2021).

12. Najduchowska, M.; Pabiś, E.; Baran, T.; Rolka, G. Properties of Concrete with the Application of Glass Cullet. IX Konferencja DNI BETONU 2016 / IX CONCRETE DAYS 2016 Conference. Available online: http:/ /icimb.pl/krakow /images/stories/Grafika/ postery/naukowe/W\%C5\%82a\%C5\%9Bciwo \%C5\%9Bci\%20betonu\%20z\%20zastosowaniem\%20st $\%$ C5\%82uczki\%20szklanej. pdf (accessed on 30 March 2021).

13. HISER International Conference, Delft, The Netherlands, 21-23 June 2017. Available online: http:/ / www.hiserproject.eu/images / mat_na_strone/Proceedings-_HISER_Conference.pdf (accessed on 30 March 2021).

14. Glass Flour as an Additive to Cement. Available online: https://artglas-recykling.pl/maczka-szklana-jako-dodatek-do-cementu (accessed on 10 February 2021).

15. EcoPact - Low-Emission Concretes. Available online: https:/ / www.lafarge.pl (accessed on 26 February 2021).

16. Holcim Süddeutschland Plans Glass Waste Use as ARM. Available online: https://www.cemnet.com/News/story/165504 /holcim-s-ddeutschland-plans-glass-waste-use-as-arm.html (accessed on 17 January 2021).

17. World of Glass. Available online: http:/ / www.swiat-szkla.pl/kontakt/14191-stuczka-szklana-w-cemencie-jak-wykorzystaodpady-szklane-w-gospodarce-o-obiegu-zamknitym.html (accessed on 17 January 2021).

18. Slow Pack-The Natural Choice. Available online: www.eko-pak.com.pl/upload/pdf/potencjal.pdf (accessed on 11 February 2021).

19. Management of Glass Waste. Available online: http://www.swiat-szkla.pl/konferencja-techniczna1/1351-zagospodarowanieodpadow-szklanych.html (accessed on 11 February 2021).

20. Ciecińska, M. Szkło odpadowe do produkcji specjalnych materiałów porowatych. Szkło Ceram. 2007, 58, 9-13.

21. SPC Polish Cement Association. Low-Carbon Cement. Available online: https://www.polskicement.pl/aktualnosci/branzacementowa-tylko-wspolistnienie-cbam-i-darmowych-alokacji-daje-nam-mozliwosci-inwestycyjne-w-nowe-technologieograniczajace-emisje-co2// (accessed on 26 February 2021).

22. Stepien, A.; Leśniak, M.; Sitarz, M. A Sustainable Autoclaved Material Made of Glass Sand. Buildings 2019, 9, 232. [CrossRef]

23. CEN. PN-EN 772-13; European Committee for Standardization (CEN): Brussels, Belgium, 2001. 
24. CEN. PN-EN 1996-2; European Committee for Standardization (CEN): Brussels, Belgium, 1996.

25. CEN. PN-EN 771-2; European Committee for Standardization (CEN): Brussels, Belgium, 2015.

26. CEN. PN-EN 1936; European Committee for Standardization (CEN): Brussels, Belgium, 2010.

27. Nocun-Wczelik, W. Struktura i najważniejsze właściwości wybranych uwodnionych krzemianów wapniowych z dodatkiem chlorków. Cem. Wapno Beton 1999, 4, 8-12.

28. Dachowski, R.; Stępień, A. Mass for the Production of Products with High Compressive Strength Features. Patent Application No. P393518, 12 December 2010.

29. Abdolhosseini Qomi, M.J.; Krakowiak, K.J.; Bauchy, M.; Stewart, K.L.; Shahsavari, R.; Jagannathan, D.; Brommer, D.B.; Baronnet, A.; Buehler, M.J.; Yip, S.; et al. Combinatorial molecular optimization of cement hydrates. Nat. Commun. 2014, 5, 1-10. [CrossRef] [PubMed]

30. Matschei, T.; Lothenbach, B.; Glasser, F. The role of calcium carbonate in cement hydration. Cem. Concr. Res. 2007, 37, 551-558. [CrossRef]

31. Skowera, K.; Rusin, Z. Physical properties of Devonian limestones from selected deposits in the context of frost resistance. Miner. Resour. Manag. 2018, 34, 71-84. 